\title{
MODULUS ELASTISITAS BERBAGAI JENIS MATERIAL
}

\author{
Budiawan Sulaeman ${ }^{1)}$ \\ ${ }^{1)}$ Dosen Program Studi Teknik Informatika, Universitas Andi Djemma, Palopo \\ 1) budiawan.unanda@yahoo.com
}

\begin{abstract}
Abstrak
Tujuan penelitian ini adalah menentukan modulus young (modulus elastisitas) dari berbagai jenis kawat logam, yaitu kawat tembaga, kawat baja dan kawat besi. Modulus young menilai keelastisan dari sebuah material perbandingan antara tegangan tarik (stress) dan regangan (strain). Modulus elastis dari Kawat baja sebesar 200,45 x $10^{9}$, pada grafik hubungan tegangan terhadap regangan menunjukkan bahwa batas elastis ada pada beban $\leq 2,5 \mathrm{~kg}$, batas plastis ada pada beban $3 \mathrm{~kg}-5,5 \mathrm{~kg}$, selanjutnya beban $\geq 6$ $\mathrm{kg}$ kawat akan putus. Kawat tembaga nilai modulus elastisnya sebesar $117,83 \times 10^{9}$, pada grafik menunjukkan batas elastis ada pada beban $\leq 1,0 \mathrm{~kg}$, batas plastis ada pada beban $1,5 \mathrm{~kg}-3,0 \mathrm{~kg}$, selanjutnya beban $\geq 3,5 \mathrm{~kg}$ akan putus. Kawat besi nilai modulus elastisnya sebesar $178,29 \times 10^{9}$, dari grafik menunjukkan bahwa batas elastis ada pada beban $\leq 2,0 \mathrm{~kg}$. Batas plastis ada pada beban 2,5-3,5 $\mathrm{kg}$, pada beban $\geq 4 \mathrm{~kg}$ akan putus. Penggunaan material uji menggunakan material dengan kondisi yang baik dalam menghindari terjadinya perlakuan negatif sebelum material tersebut diuji laboratorium. Dalam mendapatkan hasil maksimal, sebaiknya menggunakan alat uji tarik material mikro, agar setiap perubahan yang terjadi pada material dapat terdeteksi dan menghasilkan data yang lebih akurat.
\end{abstract}

Kata Kunci: Modulus elastisitas, tegangan, regangan, logam.

\section{PENDAHULUAN}

Perkembangan ilmu pengetahuan dan teknologi tidak terlepas dari kebudayaan masyarakat itu sendiri. Ilmu teknik atau tehnologi adalah kelompok ilmu pengetahuan yang paling banyak memberikan sumbangan pemikiran dalam perkembangan teknologi. Sebaliknya produk teknologi memberikan kemudahan berupa alat peneliti guna mengembangkan teori-teori dalam sains. Ilmu Fisika sebagai bagian dari sains yang mempelajari tentang materi atau zat yang meliputi sifat fisis, komposisi, perubahan dan energi yang dihasilkannya. Oleh karena itu, perkembangan Ilmu pengetahuan dan teknologi yang sangat pesat saat ini tidak terlepas dari ilmu fisika sebagai salah satu ilmu dasar. Selain itu, konsep-konsep fisika akan membantu kita dalam memahami ilmu lainnya, seperti kimia, ilmu kedokteran, teknologi industri, teknologi informasi dan teknologi manufaktur.

Karena sumbangsinya dalam perkembangan teknologi saat ini cukup banyak tidak terkecuali pada pembangunan gedung-gedung, menara, dan lain sebagainya, yang mana perlu kita pahami bahwasannya pembangunan tersebut memanfaatkan konsepkonsep fisika khususnya gerak harmonik sederhana dan elastisitas.

Dalam istilah sehari-hari gaya sering diartikan sebagai dorongan atau tarikan. Bila kita menarik atau mendorong suatu benda, berarti kita memberikan gaya pada benda itu. Gaya termasuk besaran vektor, karena memiliki besar dan arah. Gaya dapat mengakibatkan perubahan gerak dan (atau) bentuk suatu benda. Satuan gaya di dalam sistem SI adalah Newton (N). Satu Newton ialah gaya yang memberikan percepatan 1 $\mathrm{N} / \mathrm{Kg}$ kepada massa 1 kilogram. Ketika kita menarik atau mendorong sebuah benda, maka ada persentuhan antara tangan dan benda. Gaya yang terjadi melalui persentuhan antara benda-benda yang berinteraksi dinamakan gaya sentuh. Gaya sentuh berupa gaya otot, gaya mesin, gaya gesek, dan gaya pegas. Dari keempat gaya tersebut, gaya pegas erat hubungannya dengan elastisitas. 
Tujuan penelitian ini adalah menentukan modulus young (modulus elastisitas) dari berbagai jenis kawat logam, yaitu kawat email (tembaga), kawat baja (senar gitar) dan kawat besi. Modulus young dapat diartikan secara sederhana, yaitu hubungan besaran tegangan tarik dan regangan tarik. Lebih jelasnya adalah perbandingan antara tegangan tarik (stress) dan regangan (strain). Modulus young sangat menentukan nilai keelastisan dari sebuah material.

\section{METODOLOGI PENELITIAN}

Penelitian yang dilakukan melalui eksperimen di Laboratorium Fisika Universitas Andi Djemma Palopo dan ini diharapkan dapat memberikan sumbangsi pengetahuan tentang modulus young dari berbagai jenis kawat logam dengan menggunakan alat sederhana. Diagram alir Penelitian, sebagai berikut:

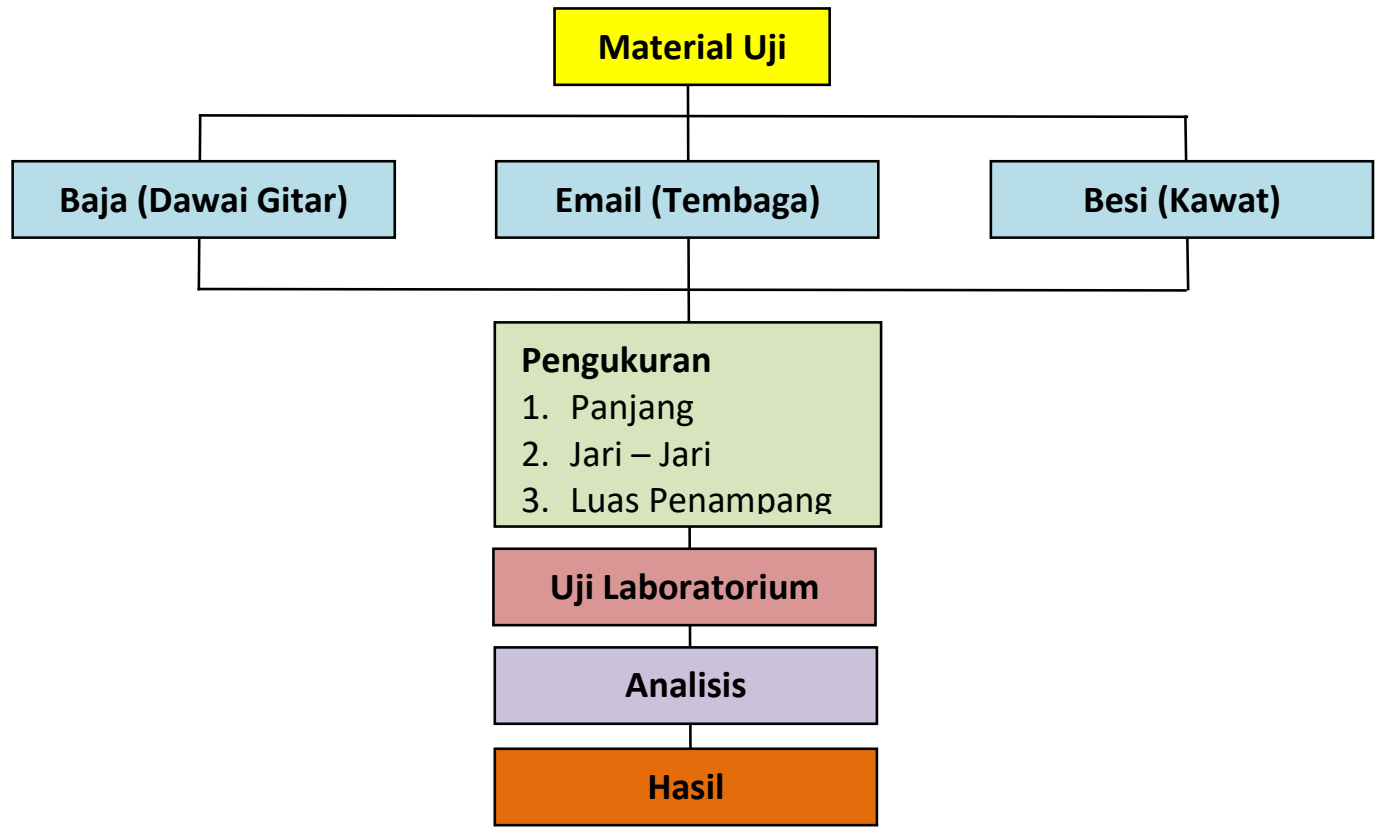

\section{Bahan/ Material dan Alat}

Gambar 1. Diagram Alir Penelitian

Material yang digunakan dalam penelitian ini adalah sebagai berikut: (a) Kawat baja/dawai gitar - Baja adalah logam paduan, logam besi yang berfungsi sebagai unsur dasar dicampur dengan beberapa elemen lainnya, termasuk unsur karbon. Besi dapat terbentuk menjadi dua bentuk kristal yaitu Body Center Cubic (BCC) dan Face Center Cubic (FCC), tergantung dari tempraturnya ketika ditempa. Dalam susunan bentuk BCC, ada atom besi ditengah-tengah kubus atom, dan susunan FCC memiliki atom besi disetiap sisi pada enam sisi kubus atom. Interaksi alotropi yang terjadi antara logam besi dengan elemen pemadu, seperti karbon, yang membuat baja dan besi tuang memiliki ciri khas yang ada pada diri mereka. Kandungan unsur karbon dalam baja berkisar antara $0.2 \%$ hingga $2.1 \%$ dari berat keseluruhan baja tersebut sesuai gradenya. Elemen berikut ini selalu ada dalam baja: karbon, mangan, fosfor, sulfur, silikon, dan sebagian kecil oksigen, nitrogen dan aluminium. Selain itu, ada elemen lain yang ditambahkan untuk membedakan karakteristik antara beberapa jenis baja diantaranya: mangan, nikel, krom, molybdenum, boron, titanium, vanadium dan niobium, b) Kawat email/tembaga - Tembaga adalah suatu unsur kimia dalam tabel periodik yang memiliki lambang $\mathrm{Cu}$ dan nomor atom 29. Lambangnya berasal dari bahasa Latin 
Cuprum.Tembaga merupakan konduktor panas dan listrik yang baik. Selain itu unsur ini memiliki korosi yang cepat sekali. Tembaga murni sifatnya halus dan lunak, dengan permukaan berwarna jingga kemerahan. Tembaga dicampurkan dengan timah untuk membuat perunggu, dan c) Kawat besi - Besi adalah unsur kimia dengan simbol Fe (dari bahasa Latin: ferrum) dan nomor atom 26. Merupakan logam dalam deret transisi pertama. Alat; stopwacth, jangka sorong, seperangkat beban, mistar panjang, micrometer dan kertas grafik (mm).

\section{Variable Penelitian}

Variabel terukur (panjang kawat, diameter kawat), variabel hitung (modulus elastisitas atau modulus young), variabel control (jenis-jenis kawat dan seperangkat beban) defenisi operasional variabel, mengukur diameter kawat digunakan mikrometer dengan ketelitian hingga $0,01 \mathrm{~mm}$, menghitung pertambahan panjang kawat setelah dibebani menggunakan jangka sorong dengan ketelitian $0,1 \mathrm{~mm}$. Sedangkan modulus elastisitas yaitu perbandingan antara tegangan tarik dan regangan tarik, dengan menggunakan seperangkat beban $0.5 \mathrm{~kg}-5.5 \mathrm{~kg}$.

\section{Teknik Pengambilan Data}

Tegangan (Stress), didefenisikan sebagai hasil bagi antara gaya tarik $\mathrm{F}$ yang dialami kawat dengan luas penampangnya (A) atau bisa juga didefenisikan sebagai gaya per satuan luas. Tegangan dirumuskan oleh:

Tegangan $=\frac{\text { Gaya }}{\text { Luas }}$ atau $\sigma=\frac{F}{A}$

Dimana, $\sigma=$ tegangan atau stress $\left(\mathrm{N} / \mathrm{m}^{2}\right), F=$ gaya tarik $(\mathrm{N}), A=$ Luas penampang $\left(\mathrm{m}^{2}\right)$

Tegangan merupakan sebuah besaran skalar dan memiliki satuan $\mathrm{N} / \mathrm{m}^{2}$ atau Pascal (Pa). Ada 5 jenis tegangan yang dapat terjadi yaitu: tegangan tarik, tegangan tekan, tegangan geser, tegangan lengkung, dan tegangan puntir.

Regangan (Strain), didefenisikan sebagai hasil bagi antara pertambahan panjang $\Delta L$ dengan panjang awalnya $L$. Atau perbandingan perubahan panjang dengan panjang awal. Regangan dirumuskan oleh:

Regangan $=\frac{\text { Pertambahan } \text { Panjang }}{\text { Panjang Awal }}$ atau $e=\frac{\Delta L}{L}$

Dimana, $\mathrm{L}=$ Panjang awal $(\mathrm{m}), \Delta \mathrm{L}=$ Perubahan ukuran panjang $(\mathrm{m}), \mathrm{e}=$ Regangan atau Strain

Karena pertambahan panjang $\Delta L$ dan panjang awal $L$ adalah besaran yang sama maka regangan $e$ tidak memiliki satuan atau dimensi.

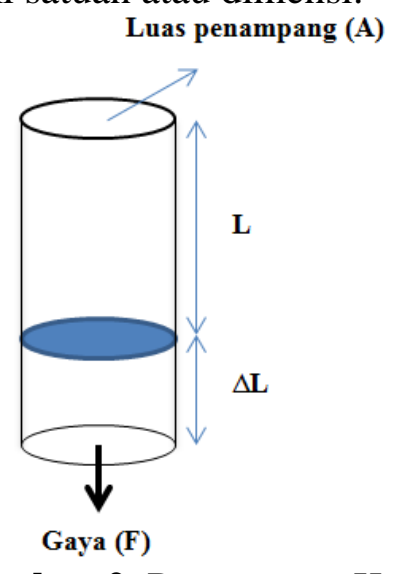

Gambar 2. Penampang Kawat 
Grafik Tegangan terhadap Regangan, Kebanyakan benda adalah elastis sampai ke suatu besar gaya tertentu dinamakan batas elastis. Jika gaya yang dikerjakan pada benda lebih kecil daripada batas elastisnya, benda akan kembali ke bentuk semula jika gaya dihilangkan. Akan tetapi, jika gaya yang diberikan melampaui batas elastis, benda tidak kembali ke bentuk semula melainkan secara permanen berubah bentuk. Grafik pada gambar 2, menunjukkan bagaimana variasi tegangan terhadap regangan ketika seutas kawat logam (baja) diberi gaya tarik sampai kawat itu patah. Dari $O$ ke $B$, deformasi (perubahan bentuk) kawat adalah elastis. Ini berarti jika tegangan dihilangkan, kawat akan kembali ke bentuk semula. Dalam daerah deformasi elastis terdapat daerah yang grafiknya linear (garis lurus). Yaitu $O A$. Dari $O$ sampai ke $A$ berlaku hukum Hooke dan $A$ disebut batas hukum Hooke. $B$ adalah batas elastis. Di atas titik ini deformasi kawat adalah plastis. Jika tegangan dihilangkan dalam daerah deformasi plastis, misalnya di titik $D$, kawat logam tidak akan kembali ke bentuk semula, melainkan mengalami deformasi atau perubahan bentuk permanen (regangan $X$ pada sumbu mendatar).

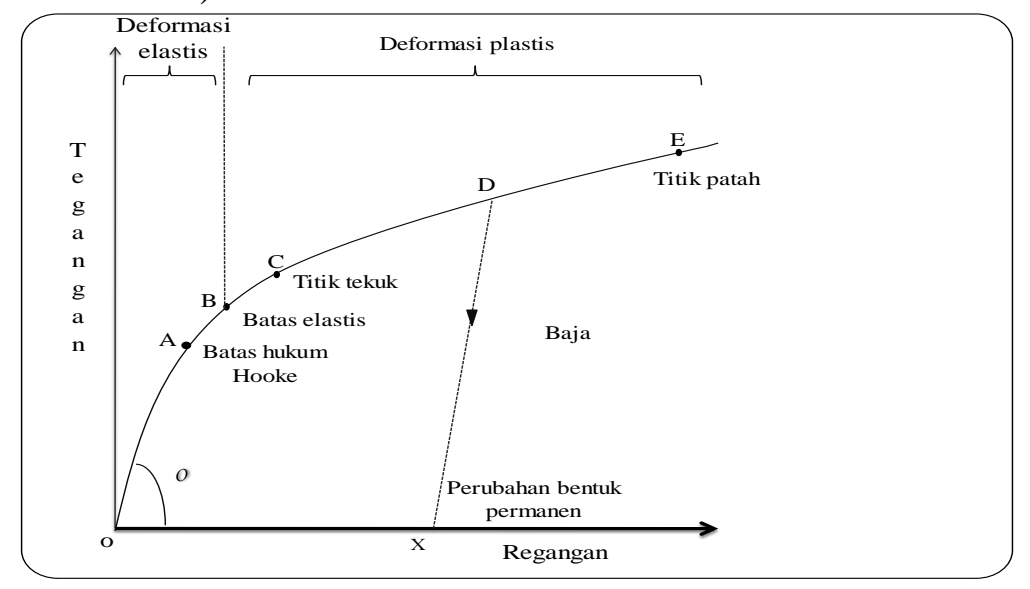

Gambar 3. Grafik Hubungan Tegangan dan Regangan

Pada titik $C$ adalah titik tekuk (yield point). Di atas titik ini hanya dibutuhkan tambahan gaya tarik kecil untuk menghasilkan pertambahan panjang yang besar. Tegangan paling besar yang dapat kita berikan tepat sebelum kawat patah disebut tegangan maksimum (ultimate tensile stress). $E$ adalah titik patah. Jika tegangan yang kita berikan mencapai titik $E$ maka kawat akan patah. untuk selanjutnya, bila kita memperhatikan grafik kembali dan memperhatikan dalam daerah OA maka grafik berbentuk garis lurus. Dimana perbandingan antara tegangan dan regangan adalah konstan. Konstanta inilah yang disebut sebagai modulus elastis atau modulus young. Dengan demikian, modulus elastis suatu bahan (E) didefenisikan sebagai perbandingan antara tegangan dan regangan yang dialami bahan, dirumuskan sebagai berikut:

Modolus Elastis $=\frac{\text { Tegangan }}{\text { Regangan }}$ atau $E=\frac{\sigma}{e}$

Dimana, $\sigma=$ tegangan $\left(\mathrm{N} / \mathrm{m}^{2}\right), \mathrm{e}=$ regangan, $\mathrm{e}=$ modulus elastis $\left(\mathrm{N} / \mathrm{m}^{2}\right)$ atau Pascal $(\mathrm{Pa})$

Jika kita subtitusikan tegangan $\sigma=F / A$ dan $e=\Delta L / L$ kedalam persamaan (3) di atas, maka diperoleh hubungan antara gaya tarik $F$ dengan modulus elastisitas $E$.

$E=\frac{\sigma}{e}=\frac{F / A}{\Delta L / L} \quad$ Maka $\frac{F}{A}=E \frac{\Delta L}{L}$ 
Tabel 1. Modulus Elastis Beberapa Zat

\begin{tabular}{lc}
\hline \multicolumn{1}{c}{ Zat } & Modulus Elastis $\left(\mathbf{N} / \mathbf{m}^{2}\right)$ \\
\hline Besi & $100 \times 10^{9}$ \\
Baja & $200 \times 10^{9}$ \\
Batubara & $14 \times 10^{9}$ \\
Marmer & $50 \times 10^{9}$ \\
Kayu & $10 \times 10^{9}$ \\
Perunggu & $100 \times 10^{9}$ \\
Aluminium & $70 \times 10^{9}$ \\
Beton & $20 \times 10^{9}$ \\
Granit & $45 \times 10^{9}$ \\
Nilon & $5 \times 10^{9}$ \\
Tulang muda & $15 \times 10^{9}$ \\
Tembaga & $120 \times 10^{9}$ \\
\hline
\end{tabular}

Tegangan Tarik, Tegangan Tekan, Tegangan Geser, Ada tiga jenis tegangan yang dikenal, yaitu tegangan tarik, tegangan tekan dan tegangan geser. Pada tegangan tekan, kedua ujung benda akan mendapatkan gaya yang sama besar dan berlawanan arah. Tapi walau pemberian gaya dilakukan di ujung-ujung benda, seluruh benda akan mengalami peregangan karena tegangan yang diberikan tersebut. Berbeda halnya dengan tegangan tarik, tegangan tekan berlawanan langsung dengan tegangan tarik. Materi yang diberi gaya bukannya ditarik melainkan ditekan sehingga gaya-gaya akan bekerja di dalam benda, contohnya seperti tiang-tiang pada kuil Yunani. Tegangan yang ketiga yaitu tegangan geser. Benda yang mengalami tegangan geser memiliki gaya-gaya yang sama dan berlawanan arah yang diberikan melintasi sisi-sisi yang berlawanan. Misalkan sebuah buku atau batu bata terpasang kuat dipermukaan. Meja memberikan gaya yang sama dan berlawanan arah sepanjang permukaan bawah. Walau dimensi benda tidak banyak berubah, bentuk benda berubah. Bila ketiga tegangan tersebut diberikan terlalu besar, melebihi kekuatan benda maka benda tersebut akan patah.

Gaya internal yang bekerja pada beberapa luasan elemen yang kecil, untuk tujuan perbandingan kita memperlakukan gaya normal yang bekerja pada suatu unit luasan pada penampang melintang. Intensitas gaya normal per unit luasan disebut tegangan normal dan dinyatakan dalam unit gaya per unit luasan, misalnya $\mathrm{ib} / \mathrm{in}^{2}$, atau $\mathrm{N} / \mathrm{m}^{2}$. Apabila gaya-gaya dikenakan pada ujung-ujung batang sedemikian sehingga batang dalam kondisi tertarik, maka terjadi suatu Tegangan tarik pada batang; jika batang dalam kondisi tertekan maka terjadi tegangan tekan. Perlu dicatat bahwa garis aksi dari gaya yang bekerja adalah melalui pusat setiap bagian penampang melintang batang.

Kurva Tegangan-Regangan, Sebagaimana beban aksial yang bertambah bertahap, pertambahan panjang terhadap panjang gage diukur pada setiap pertambahan beban dan ini dilanjutkan sampai terjadi kerusakan (fracture) pada bahan. Dengan mengetahui luas penampang awal, maka tegangan normal yang dinyatakan dengan $\sigma$ dapat diperoleh untuk setiap nilai beban aksial dengan menggunakan hubungan $\sigma=$ $P / A$ dimana $P$ menyatakan beban aksial dalam Newton dan $A$ menyatakan luas penampang awal dalam $\mathrm{m}^{2}$. Dengan memasangkan pasangan nilai tegangan normal dengan regangannya, data percobaan dapat digambarkan dengan memperlakukan kuantitas-kuantitas ini sebagai absis dan ordinat. Berikut gambar yang diperoleh 
adalah diagram atau kurva tegangan-regangan. Kurva tegangan-regangan mempunyai bentuk yang berbeda-beda tergantung dari bahannya.

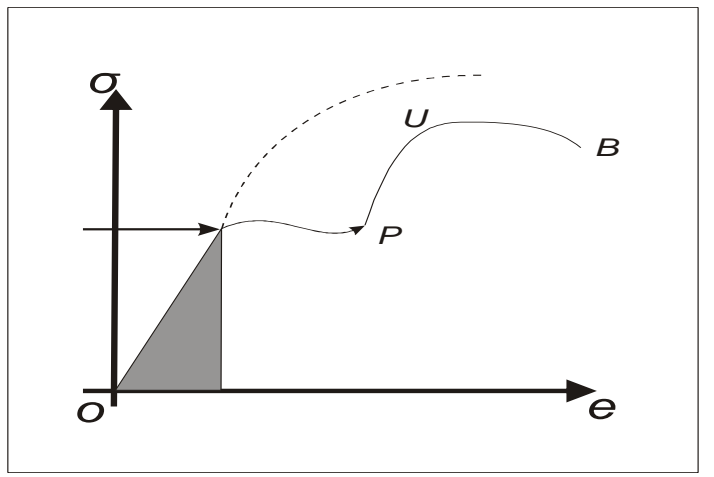

Gambar 4a. Kurva TeganganRegangan untuk Baja KarbonMedium.

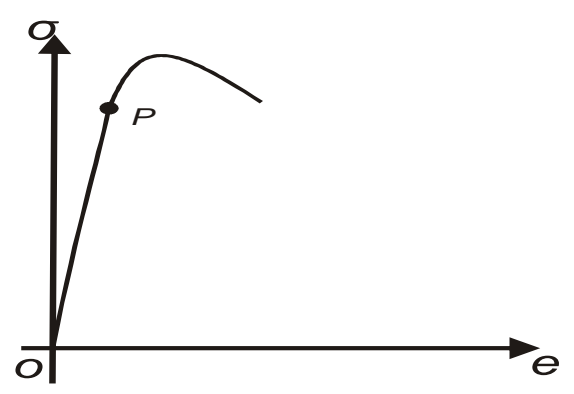

Gambar 4c. Kurva TeganganRegangan Untuk Baja Karbon-Tinggi dengan Campuran Bahan Nonferrous

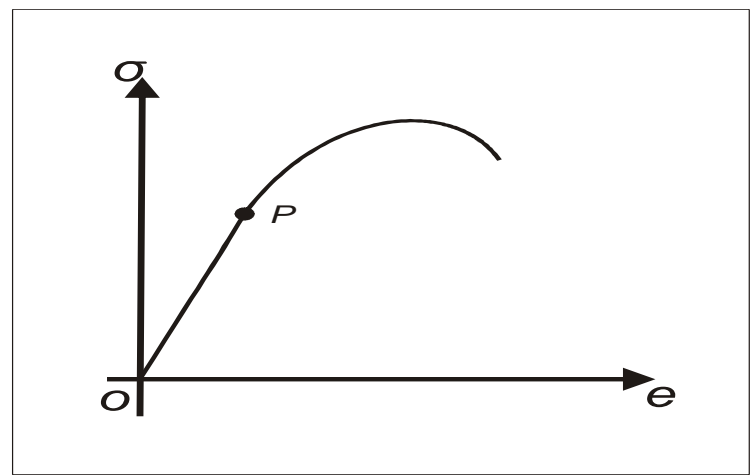

Gambar 4b. Kurva Tegangan-

Regangan untuk Baja Campuran

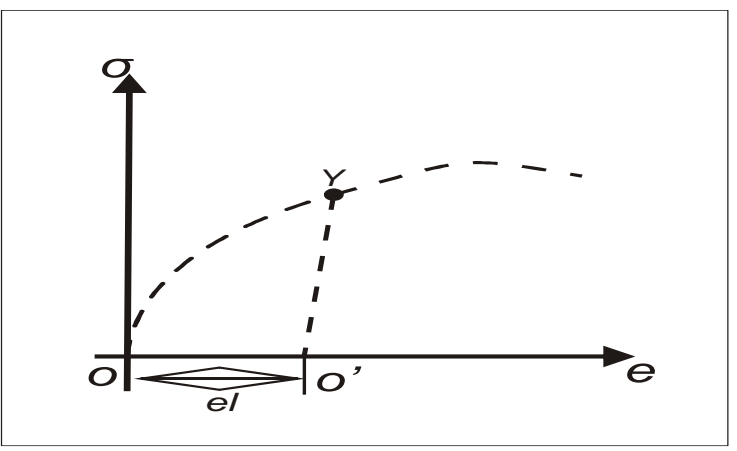

Gambar 4d. Kurva Tegangan-Regangan untuk Baja Karbon-Tinggi dengan Campuran Bahan Nonferrous Dengan Besi

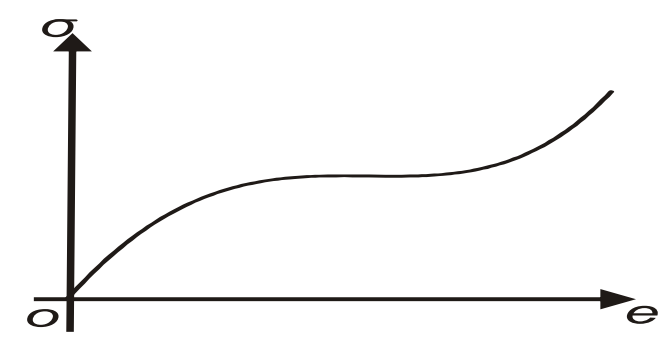

Gambar 4e. Kurva Tegangan-Regangan untuk Karet

Hukum Hooke, Percobaan yang kita lakukan pada dasarnya adalah untuk mengetahui hubungan kuantitatif antara gaya yang dikerjakan pada pegas dengan pertambahan panjangnya. Jika dibuat grafik gaya tarik terhadap perubahan panjang, maka akan anda dapatkan grafik membentuk sebuah garis linear. Hukum Hooke sendiri berbunyi, "jika gaya tarik tidak melampaui batas elastis pegas, maka pertambahan panjang pegas berbanding lurus (sebanding) dengan gaya tariknya". 
Pertanyaan ini dikemukakan oleh Robert Hooke, seorang arsitek yang ditugaskan membangun kembali gedung-gedung di London yang mengalami kebakaran pada tahun 1666. Oleh karena itu, pernyataan ini dikenal sebagai Hukum Hooke. Hukum Hooke dapat dirumuskan sebagai berikut:

$F=k \Delta x$

Dimana, $\mathrm{k}=$ Tetapan gaya $(\mathrm{N} / \mathrm{cm}), \Delta \mathrm{x}=$ Pertambahan panjang $(\mathrm{cm})$

Tetapan Gaya Benda Elastis dalam Hukum Hooke dilambangkan dengan simbol k. Perlu kita ketahui bahwa tetapan gaya $\mathrm{k}$ adalah tetapan umum yang berlaku untuk benda elastis jika diberi gaya yang tidak melampaui titik $A$ (batas Hukum Hooke). Untuk menentukan tetapan gaya $k$ dari suatu benda elastis kawat logam, perhatikan pers 4 dan 5. Jika pada persamaan 4 kita olah, hingga di ruas kiri hanya terdapat gaya tarik $F$ dan persamaan di identikkan dengan Hukum Hooke (Pers. 5), kita peroleh rumus umum untuk menghitung tetapan gaya $\mathrm{k}$ suatu benda elastis. Dengan menyamakan ruas kanan kedua persamaan di atas kita peroleh rumus umum tetapan gaya $\mathrm{k}$ untuk suatu benda elastis, yaitu;

$k=\frac{\mathrm{AE}}{\mathrm{L}}$

Dimana, $A=$ Luas penampang $(\mathrm{m} 2), \mathrm{E}=$ Modulus elastis bahan $(\mathrm{N} / \mathrm{m} 2), \mathrm{L}=$ Panjang bebas benda sebelum ditarik

\section{Data Konversi}

Mengukur diameter kawat dengan menggunakan mikrometer sekrup kemudian menentukan luas penampangnya dengan menggunakan persamaan sebagai berikut:

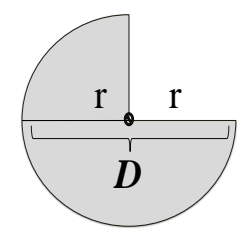

Gambar 5. Penampang pada Lingkaran.

Kita ketahui $\mathrm{D}=2 \mathrm{r}$, maka persamaan di atas adalah untuk mencari luas lingkaran dalam hal ini adalah luas penampang

$\mathrm{A}=\pi r^{2}$

Dimana: $r=$ jari-jari lingkaran $(\mathrm{m}), \pi=(\mathrm{Pi})$ senilai $3,14, \mathrm{~A}=$ luas penampang $(\mathrm{m})$

Menentukan panjang kawat yang akan ditentukan modulus youngnya dengan menggunakan mistar atau meteran.

\section{Data Pengukuran}

Catat kedudukan skala nonius terhadap skala. Tambahkan beban pada salah satu material uji berturut-turut dengan penambahan massa $0,5 \mathrm{~kg}$ pada setiap penambahan bebannya. setelah beberapa saat (kira-kira 30 detik), catatlah kedudukan skala nonius. Lakukan penambahan sampai material uji terputus. Hitung pertambahan panjang untuk setiap penambahan beban. Hitung tegangan tarik dan regangan tarik pada setiap langkah penambahan. Sehingga menghasilkan grafik hubungan antara tegangan tarik dan regangannya. 


\section{Teknik Analisa Data}

Data yang diperoleh di analisis secara deskriptif berupa gambaran dalam bentuk tabel, angka-angka, dan grafik yang disertai dengan pembahasan yang menggunakan Aplikasi Microsoft Office Excel 2010.

\section{HASIL DAN PEMBAHASAN \\ Hasil}

Penelitian diawali dengan menentukan panjang kawat dan diameter kawat kemudian menghitung luas penampangnya. Besarnya luas penampang dan panjang tiap jenis kawat dapat dilihat pada table berikut:

Tabel 2. Perbandingan Panjang Kawat dan Luas Penampangnya

\begin{tabular}{clccc}
\hline No. & Jenis Kawat & $\begin{array}{c}\text { Panjang Kawat } \\
(\mathbf{L})\end{array}$ & $\begin{array}{c}\text { Jari }- \text { Jari } \\
\text { Kawat }(\mathbf{r})\end{array}$ & $\begin{array}{c}\text { Luas Penampang } \\
(\mathbf{A})\end{array}$ \\
\hline $\mathbf{1}$ & Baja (dawai gitar) & $700 \times 10^{-3} \mathrm{~m}$ & $1.95 \times 10^{-4} \mathrm{~m}$ & $11.94 \times 10^{-8}$ \\
\hline $\mathbf{2}$ & Email (tembaga) & $700 \times 10^{-3} \mathrm{~m}$ & $2.25 \times 10^{-4} \mathrm{~m}$ & $15.89 \times 10^{-8}$ \\
\hline $\mathbf{3}$ & Besi & $700 \times 10^{-3} \mathrm{~m}$ & $1.75 \times 10^{-4} \mathrm{~m}$ & $9.62 \times 10^{-8}$ \\
\hline
\end{tabular}

Pengambilan data selanjutnya yaitu menghitung tegangan tarik dan regangan tariknya. Tegangan tarik diperoleh dengan membagi gaya tarik dengan luas penampangnya, gaya tarik disini yaitu massa dikali dengan gaya gravitasi bumi $(9,8$ $\mathrm{m} / \mathrm{s}^{2}$ ). Data yang diperoleh dari perlakuan ini adalah data konversi, yaitu mengetahui panjang kawat, jari-jari kawat, luas penampang kawat. Selanjutnya mengukur pertambahan panjang pada skala dengan penambahan beban dari $0,5 \mathrm{~kg}$ sampai material uji terputus, data ini selanjutnya disebut sebagai data hasil pengukuran. Berikut adalah tabel penambahan beban pada kawat baja, kawat tembaga dan kawat besi.

1) Kawat baja

Tabel 3. Perbandingan Tegangan Tarik dan Regangan Pada Kawat Baja

\begin{tabular}{cccccc}
\hline $\begin{array}{c}\text { Massa } \\
(\mathbf{k g})\end{array}$ & $\begin{array}{c}\text { Gaya } \\
(\mathbf{N})\end{array}$ & $\mathbf{L t}(\mathbf{m})$ & $\Delta \mathbf{L}(\mathbf{m})$ & $\boldsymbol{\sigma}\left(\mathbf{N} / \mathbf{m}^{2}\right)$ & $\mathbf{e}=\Delta \mathbf{L} / \mathbf{L}$ \\
\hline 0.5 & 4.9 & $70.1 \times 10^{-3}$ & $0.1 \times 10^{-3}$ & $4.10 \times 10^{7}$ & $1.43 \times 10^{-4}$ \\
\hline 1.0 & 9.8 & $70.25 \times 10^{-3}$ & $0.25 \times 10^{-3}$ & $8.21 \times 10^{7}$ & $3.57 \times 10^{-4}$ \\
\hline 1.5 & 14.7 & $70.4 \times 10^{-3}$ & $0.4 \times 10^{-3}$ & $12.31 \times 10^{7}$ & $5.71 \times 10^{-4}$ \\
\hline 2.0 & 19.6 & $70.6 \times 10^{-3}$ & $0.6 \times 10^{3}$ & $16.42 \times 10^{7}$ & $8.57 \times 10^{-4}$ \\
\hline 2.5 & 24.5 & $70.8 \times 10^{-3}$ & $0.8 \times 10^{-3}$ & $20.52 \times 10^{7}$ & $11.43 \times 10^{-4}$ \\
\hline 3.0 & 29.4 & $71.1 \times 10^{-3}$ & $1.1 \times 10^{-3}$ & $24.62 \times 10^{7}$ & $15.71 \times 10^{-4}$ \\
\hline 3,5 & 34.3 & $71.7 \times 10^{-3}$ & $1.7 \times 10^{-3}$ & $28.73 \times 10^{7}$ & $24.28 \times 10^{-4}$ \\
\hline 4.0 & 39.2 & $72.5 \times 10^{-3}$ & $2.5 \times 10^{-3}$ & $32.83 \times 10^{7}$ & $35.71 \times 10^{-4}$ \\
\hline 4.5 & 44.1 & $73.4 \times 10^{-3}$ & $3.4 \times 10^{-3}$ & $36.93 \times 10^{7}$ & $48.57 \times 10^{-4}$ \\
\hline 5.0 & 49 & $74.45 \times 10^{-3}$ & $4.45 \times 10^{-3}$ & $41.04 \times 10^{7}$ & $63.57 \times 10^{-4}$ \\
\hline 5.5 & 53.9 & $75.4 \times 10^{-3}$ & $5.4 \times 10^{-3}$ & $45.14 \times 10^{7}$ & $77.14 \times 10^{-4}$ \\
\hline \multicolumn{7}{c}{ Material uji kawat baja putus/ patah } \\
\hline \multicolumn{7}{c}{}
\end{tabular}




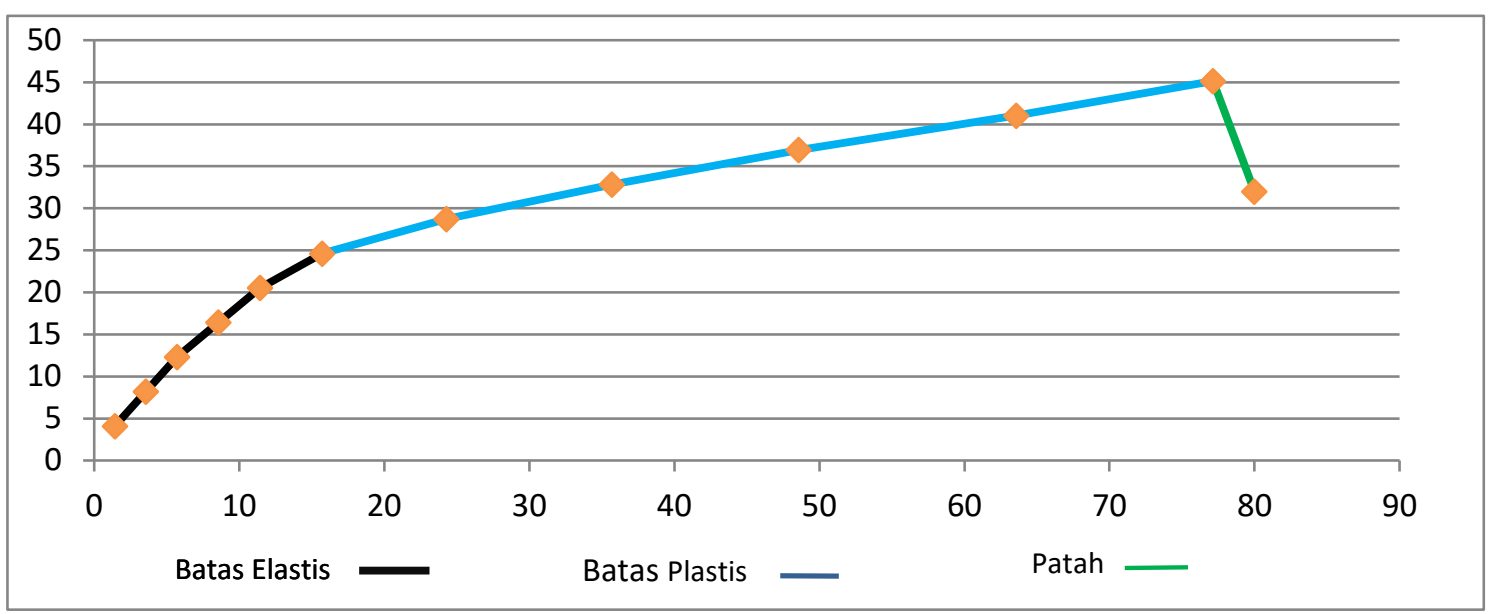

Gambar 6. Grafik Perbandingan Tegangan Terhadap Regangan pada Kawat Baja

Dari grafik di atas menunjukkan bahwa batas elastis untuk kawat baja adalah pada beban $2,5 \mathrm{~kg}$. Untuk penambahan beban secara berturut-turut dari $0,5 \mathrm{~kg}$ sampai $2,5 \mathrm{~kg}$ (lihat tabel 3) didapat jumlah rata-rata tegangan dan regangan, sehingga besar Modulus Elastis dari kawat baja diperoleh dari persamaan 2 adalah 187,36 x 10 ${ }^{9} \mathrm{~N} / \mathrm{m}^{2}$.

2) Kawat tembaga

Tabel 4. Perbandingan Tegangan Tarik dan Regangan pada Kawat Tembaga

\begin{tabular}{cccccc}
\hline $\begin{array}{c}\text { Massa } \\
(\mathbf{k g})\end{array}$ & $\begin{array}{c}\text { Gaya } \\
(\mathbf{N})\end{array}$ & $\mathbf{L t}(\mathbf{m})$ & $\Delta \mathbf{L}(\mathbf{m})$ & $\boldsymbol{\sigma}\left(\mathbf{N} / \mathbf{m}^{2}\right)$ & $\mathbf{e}=\Delta \mathbf{L} / \mathbf{L}$ \\
\hline 0.5 & 4.9 & $70.15 \times 10^{-3}$ & $0.15 \times 10^{-3}$ & $3.08 \times 10^{7}$ & $2.14 \times 10^{-4}$ \\
\hline 1.0 & 9.8 & $70.4 \times 10^{-3}$ & $0.4 \times 10^{-3}$ & $6.17 \times 10^{7}$ & $5.71 \times 10^{-4}$ \\
\hline 1.5 & 14.7 & $70.9 \times 10^{-3}$ & $0.9 \times 10^{-3}$ & $9.25 \times 10^{7}$ & $12.86 \times 10^{-4}$ \\
\hline 2.0 & 19.6 & $70.6 \times 10^{-3}$ & $1.5 \times 10^{3}$ & $12.33 \times 10^{7}$ & $21.43 \times 10^{-4}$ \\
\hline 2.5 & 24.5 & $70.8 \times 10^{-3}$ & $2.25 \times 10^{-3}$ & $15.42 \times 10^{7}$ & $32.14 \times 10^{-4}$ \\
\hline 3.0 & 29.4 & $71.1 \times 10^{-3}$ & $3.1 \times 10^{-3}$ & $18.5 \times 10^{7}$ & $44.29 \times 10^{-4}$ \\
\hline
\end{tabular}

Material uji kawat tembaga putus/ patah

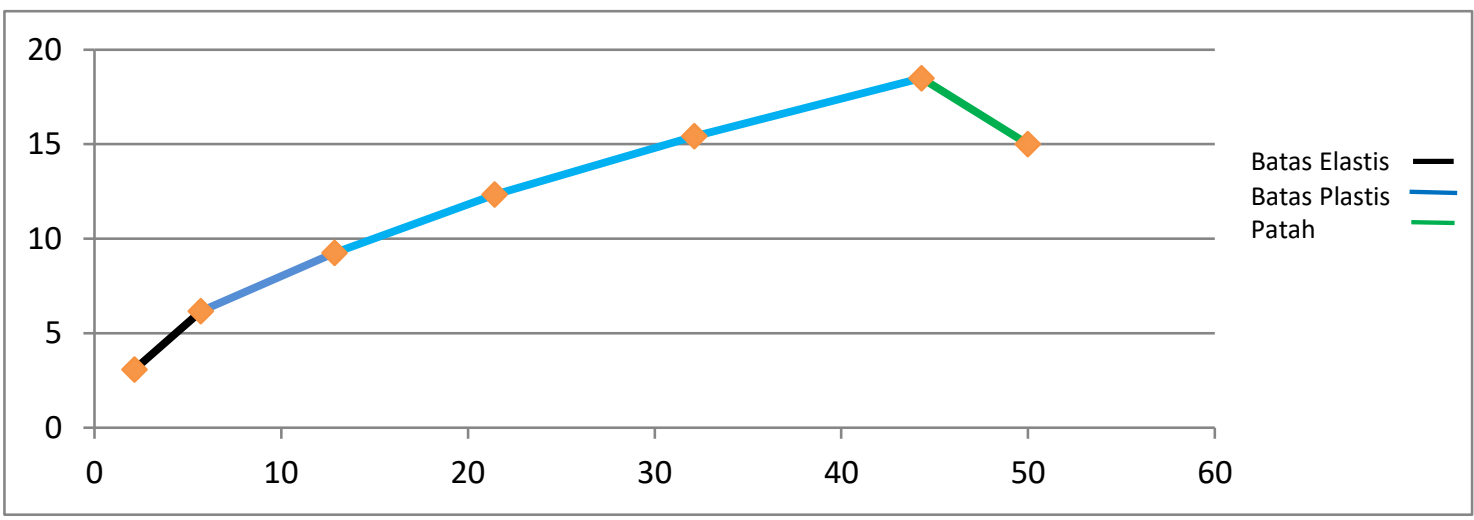

Gambar 11. Grafik Perbandingan Tegangan terhadap Regangan pada Kawat Tembaga

Dari grafik di atas menunjukkan bahwa batas elastis untuk kawat tembaga adalah pada beban $1,0 \mathrm{~kg}$. Untuk penambahan beban secara berturut-turut dari $0,5 \mathrm{~kg}$ sampai $1,0 \mathrm{~kg}$ (lihat tabel 4) didapat jumlah rata-rata tegangan dan regangan, sehingga besar Modulus Elastis dari kawat tembaga diperoleh dari persamaan 2 adalah $108 \times 10^{9}$ $\mathrm{N} / \mathrm{m}^{2}$. 
3) Kawat besi

Tabel 5. Perbandingan Tegangan Tarik dan Regangan pada Kawat Besi

\begin{tabular}{cccccc}
\hline $\begin{array}{c}\text { Massa } \\
(\mathbf{k g})\end{array}$ & $\begin{array}{c}\text { Gaya } \\
(\mathbf{N})\end{array}$ & $\mathbf{L t}(\mathbf{m})$ & $\Delta \mathbf{L}(\mathbf{m})$ & $\boldsymbol{\sigma}\left(\mathbf{N} / \mathbf{m}^{2}\right)$ & $\mathbf{e}=\Delta \mathbf{L} / \mathbf{L}$ \\
\hline 0.5 & 4.9 & $70.2 \times 10^{-3}$ & $0.2 \times 10^{-3}$ & $5.09 \times 10^{7}$ & $2.86 \times 10^{-4}$ \\
\hline 1.0 & 9.8 & $70.4 \times 10^{-3}$ & $0.4 \times 10^{-3}$ & $10.19 \times 10^{7}$ & $5.71 \times 10^{-4}$ \\
\hline 1.5 & 14.7 & $70.7 \times 10^{-3}$ & $0.6 \times 10^{-3}$ & $15.28 \times 10^{7}$ & $8.57 \times 10^{-4}$ \\
\hline $\mathbf{2 . 0}$ & 19.6 & $70.6 \times 10^{-3}$ & $0.8 \times 10^{3}$ & $20.37 \times 10^{7}$ & $11.43 \times 10^{-4}$ \\
\hline 2.5 & 24.5 & $71.5 \times 10^{-3}$ & $1.2 \times 10^{-3}$ & $25.47 \times 10^{7}$ & $17.14 \times 10^{-4}$ \\
\hline 3.0 & 29.4 & $72.0 \times 10^{-3}$ & $1.7 \times 10^{-3}$ & $30.5 \times 10^{7}$ & $24.29 \times 10^{-4}$ \\
\hline $\mathbf{3 , 5}$ & 34.3 & $72.3 \times 10^{-3}$ & $2.3 \times 10^{-3}$ & $35.65 \times 10^{7}$ & $32.8610^{-4}$ \\
\hline \multicolumn{6}{c}{ Material uji kawat besi putus/ patah } \\
\end{tabular}

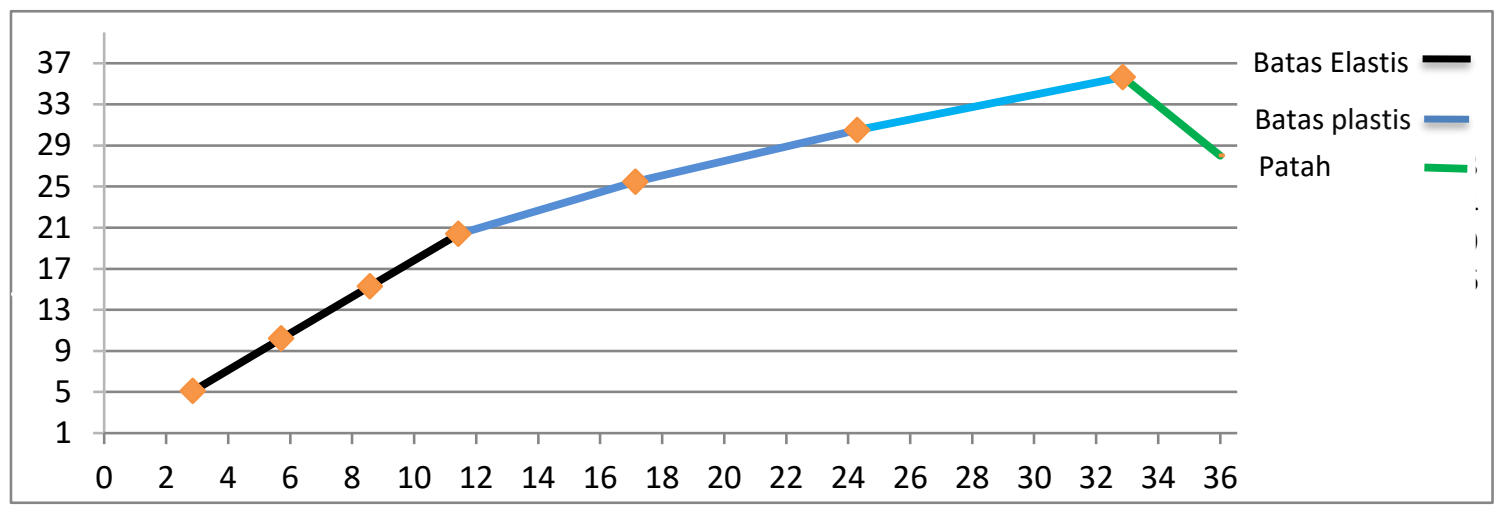

Gambar 12. Grafik Perbandingan Tegangan terhadap Regangan pada Kawat Besi

Dari grafik di atas menunjukkan bahwa batas elastis untuk kawat besi adalah pada beban $2,0 \mathrm{~kg}$. Untuk penambahan beban secara berturut-turut dari $0,5 \mathrm{~kg}$ sampai $2,0 \mathrm{~kg}$ (lihat tabel 5) didapat jumlah rata-rata tegangan dan regangan, sehingga besar Modulus Elastis dari kawat besi diperoleh dari persamaan 2 adalah $178,29 \times 10^{9} \mathrm{~N} / \mathrm{m}^{2}$.

\section{Pembahasan}

Setelah melakukan eksperimen, hasil pengujian laboratorium tidak sesuai dengan teori dan sedikit menyimpang, tetapi penyimpangan tersebut tidak terlalu besar seperti modulus elastis dari kawat baja diperoleh sebesar 200,45 × $10^{9}$ sementara nilai modulus elastis (Tabel 1) sebesar $200 \times 10^{9}$, pada grafik hubungan tegangan terhadap regangan untuk kawat baja menunjukkan bahwa batas elastis ada pada beban $\leq 2,5 \mathrm{~kg}$ kemudian batas plastis ada pada beban $3 \mathrm{~kg}-5,5 \mathrm{~kg}$, selanjutnya kawat diberi beban $\geq$ $6 \mathrm{~kg}$ maka kawat akan putus. Untuk kawat tembaga sebesar $117,83 \times 10^{9}$ dan nilai modulus elastis (Tabel 1) sebesar $120 \times 10^{9}$, dari grafik menunjukkan bahwa batas elastis ada pada beban $\leq 1,0 \mathrm{~kg}$ kemudian untuk batas plastis ada pada beban $1,5 \mathrm{~kg}-$ $3,0 \mathrm{~kg}$, pada beban $\geq 3,5 \mathrm{~kg}$ kawat akan putus. Untuk kawat besi modulus elastisnya sebesar 178,29 × $10^{9}$ dan nilai modulus elastis (Tabel 1) sebesar $100 \times 10^{9}$, dari grafik menunjukkan bahwa batas elastis ada pada beban $\leq 2,0 \mathrm{~kg}$. Kemudian untuk batas plastis ada pada beban $2,5-3,5 \mathrm{~kg}$, pada beban $\geq 4 \mathrm{~kg}$ kawat akan putus, pada data ini sangat besar penyimpangannya. Selanjutnya jika dilihat dari hasil pengamatan grafik, setiap ditambah beban kawat selalu bertambah panjang, namun saat dituliskan dalam grafik, grafik memang linear tetapi agak bengkok sehingga tidak konstan padahal dalam teori seharusnya grafik tersebut linear dan bernilai konstan. Kedua hal di atas 
dimungkinkan karena faktor alat dan material uji terutama kawat yang digunakan. Hal ini dimungkinkan karena kondisi kawat yang sudah tidak baik dan keelastisannya sudah berkurang bahkan cenderung sudah berubah menjadi benda dengan bersifat plastik. Kawat ini seharusnya bersifat elastis, dimana jika diberi gaya bentuknya akan berubah dan kembali kebentuk semula bila gaya dilepaskan. Tetapi sekarang kawat tersebut sudah bersifat plastik sehingga saat diberi gaya dan saat gaya itu dilepaskan dari kawat, kawat tidak kembali ke bentuk dan ukuran semula. Akhirnya hal itu membuat data-data yang didapat saat pengamatan menjadi tidak akurat.

\section{KESIMPULAN}

Berdasarkan hasil penelitian dan pembahasan maka dapat disimpulkan bahwa; modulus elastis dari kawat baja diperoleh sebesar 200,45 x $10^{9}$, pada grafik hubungan tegangan terhadap regangan untuk kawat baja menunjukkan bahwa batas elastis ada pada beban $\leq 2,5 \mathrm{~kg}$ kemudian batas plastis ada pada beban $3 \mathrm{~kg}-5,5 \mathrm{~kg}$, selanjutnya kawat diberi beban $\geq 6 \mathrm{~kg}$ maka kawat akan putus. Kawat tembaga sebesar 117,83 x $10^{9}$, dari grafik menunjukkan bahwa batas elastis ada pada beban $\leq 1,0 \mathrm{~kg}$ kemudian untuk batas plastis ada pada beban $1,5 \mathrm{~kg}-3,0 \mathrm{~kg}$, pada beban $\geq 3,5 \mathrm{~kg}$ kawat akan putus. Kawat besi modulus elastisnya sebesar $178,29 \times 10^{9}$, dari grafik menunjukkan bahwa batas elastis ada pada beban $\leq 2,0 \mathrm{~kg}$. Kemudian untuk batas plastis ada pada beban $2,5-3,5 \mathrm{~kg}$, pada beban $\geq 4 \mathrm{~kg}$ kawat akan putus.

\section{DAFTAR PUSTAKA}

Ashby, Michael F. and Jones, David R. H. (1992) [1986]. Engineering Materials 2 (edisi ke-with corrections). Oxford: Pergamon Press. ISBN 0-08-032532-7

Askeland, Donald R.; Phulé, Pradeep P. (2006). The science and engineering of materials (edisi ke-5th). Cengage Learning. hlm. 198. ISBN 978-0-534-553968.

Atanackovic, Teodor M.; Guran, Ardéshir (2000). "Hooke's law". Theory of elasticity for scientists and engineers. Boston, Mass.: Birkhäuser. hlm. 85. ISBN 978-08176-4072-9.

Beer, Ferdinand P.; Johnston, E. Russell; Dewolf, John; Mazurek, David (2009). Mechanics of Materials. McGraw Hill. hlm. 56. ISBN 978-0-07-015389-9

Bigoni, D. Nonlinear Solid Mechanics (2012): Bifurcation Theory and Material Instability. Cambridge University Press. ISBN 978-1-107-02541-7

Demazeau, G.; Buffat, B.; Pouchard, M.; Hagenmuller, P. (1982). "Recent developments in the field of high oxidation states of transition elements in oxides stabilization of Six-coordinated Iron(V)". Zeitschrift für 
PENA TEKNIK: Jurnal Ilmiah Ilmu-Ilmu Teknik

Volume 3, Nomor 2, September 2018 :127 - 138

Halaman ini sengaja dikosongkan 